\title{
Synthesis of Two Potentially Heptadentate (N4O3) Schiff-base Ligands Derived from Condensation of Tris(3-aminopropyl)- amine and Salicylaldehyde or 4-Hydroxysalicylaldehyde. Nickel(II) and Copper(II) Complexes of the Former Ligand.
}

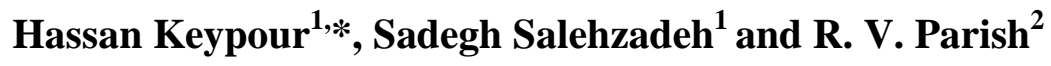

1 Department of Chemistry, Bu-Ali Sina University, Hamadan, Zip Code 65174, Iran, Fax (+98) 818272404

2 Department of Chemistry, UMIST, PO Box 88, Manchester M60 1QD, UK.

* Author to whom correspondence should be addressed; e-mail: keypour@basu.ac.ir

Received: 9 December 2000; in revised form: 6 February 2002 / Accepted: 11 February 2002 / Published: 28 February 2002

\begin{abstract}
Two potentially heptadentate $\left(\mathrm{N}_{4} \mathrm{O}_{3}\right)$ tripodal Schiff-base ligands: tris(3(salicylideneimino)propyl)amine $\left(\mathrm{H}_{3} \mathrm{~L} 1\right)$ and tris(3-(4'-hydroxysalicylideneimino)propyl)amine $\left(\mathrm{H}_{3} \mathrm{~L} 2\right)$ have been prepared and characterized by various spectroscopic methods (IR, FAB-MS, NMR). They are derived from the condensation reactions of tris(3-aminopropyl)amine (tpt), with 3 equivalents of either salicylaldehyde or the ringsubstituted salicylaldehyde, 4-hydroxysalicylaldehyde. The nickel(II) and copper(II) complexes of $\mathrm{H}_{3} \mathrm{~L} 1$ were obtained from the its reactions $\mathrm{Ni}(\mathrm{II})$ and $\mathrm{Cu}$ (II) salts in absolute methanol. These complexes were studied by IR and FAB-Mass spectrometry.
\end{abstract}

Keywords: Schiff-base, tripodal ligands, potentially heptadentate complexes 


\section{Introduction}

Potentially heptadentate $\left(\mathrm{N}_{4} \mathrm{O}_{3}\right)$ Schiff-base ligands, derived from condensation reactions of tris(2aminoethyl)amine (tren) with various ring substituted salicylaldehydes, have been prepared, and their coordination chemistry with a number of metal ions has been extensively investigated [1-5]. The amine phenol ligands, which have been prepared from the reduction of the corresponding Schiff-base ligands, have been also reported [6]. We and other workers have prepared complexes of fully condensed potentially heptadentate $\left(\mathrm{N}_{7}\right)$ Schiff-base ligands derived from the condensation of tripodal tetraamines with either 2-acetylpyridine or 2-pyridinecarboxaldehyde [7-10]. However, herein we report the synthesis of the two potentially heptadentate $\left(\mathrm{N}_{4} \mathrm{O}_{3}\right)$ Schiff-base ligands, $\mathrm{H}_{3} \mathrm{~L} 1$ and $\mathrm{H}_{3} \mathrm{~L} 2$ (Figure1) together with the synthesis of nickel(II) and copper(II) complexes of $\mathrm{H}_{3} \mathrm{~L} 1$.

Figure 1. The procedure of ligand synthesis, along with NMR numbering

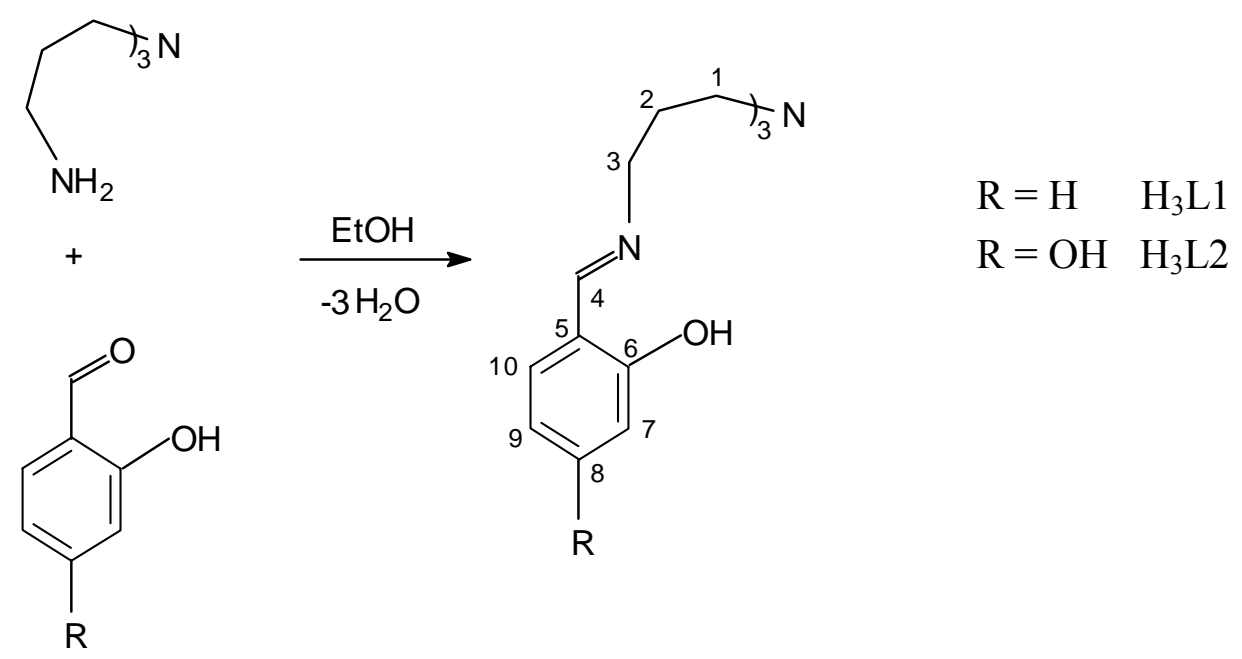

\section{Results and discussion}

\section{Ligands}

Two potentially heptadentate Schiff-base ligands were easily prepared by reaction of tris(3-aminopropyl)amine with 3 equivalent of salicylaldehyde or its 4-substituted derivative, as shown in Figure1. They are both sensitive to moisture and must be kept under vacuum. Complete condensation of all primary amino groups is confirmed by the lack of N-H stretching bands in the IR $3150-3450 \mathrm{~cm}^{-1}$ region and the presence of strong $\mathrm{C}=\mathrm{N}$ stretching bands for both $\mathrm{H}_{3} \mathrm{~L} 1$ and $\mathrm{H}_{3} \mathrm{~L} 2$ ligands. This conclusion is also supported by the ${ }^{1} \mathrm{H}-\mathrm{NMR}$ data which shows not only the absence of N-H hydrogen resonances but also the presence of $\mathrm{CH}=\mathrm{N}$ Hydrogen resonances at about $8 \mathrm{ppm} .{ }^{1} \mathrm{H}-$ and ${ }^{13} \mathrm{C}-\mathrm{NMR}$ spectra, mass spectral and infrared data for both ligands are completely consistent with the formulations indicated in Figure 1. 


\section{Complexes}

Both complexes were investigated by elemental analysis, IR and FAB mass spectrometry. The lack of N-H stretching bands in the IR $3150-3450 \mathrm{~cm}^{-1}$ region and the presence of very strong C=N (Schiffbase) stretching bands at about $1630 \mathrm{~cm}^{-1}$ for both compounds show that the expected complexes were synthesized. The mass spectral data for complexes $\mathbf{1}$ and $\mathbf{2}$ are consistent with deprotonation of two of the three hydroxyl groups of the ligand, giving neutral complexes (Figure 2). The latter conclusion is also supported by the insolubility of these complexes in water. In both complexes the bridgehead nitrogen atom may be coordinated to the metal ions, as we have observed for the corresponding complexes derived from 2-acetylpyridine [7, 10].

Figure 2. The proposed chemical structure for the complexes $\mathbf{1}$ and $\mathbf{2}$.

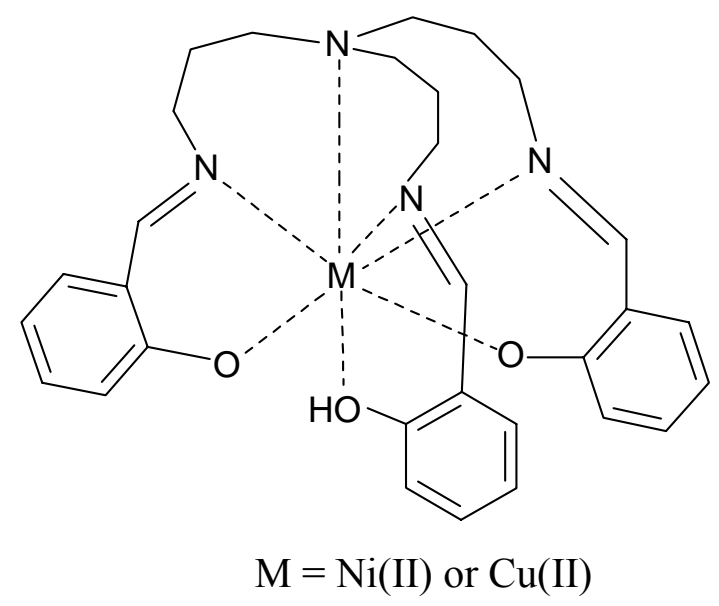

\section{Experimental}

\section{General}

Salicylaldehyde and 4-hydroxysalicylaldehyde were obtained from Aldrich and were used without further purification. The tripodal tetraamine ligand tpt was synthesized according to the literature method [11]. IR and NMR spectra were measured on Shimadzu IR-435 and Bruker DPX 300 spectrometers respectively.

\section{Ligand synthesis}

Tris(3-(salicylideneimino)propyl)amine $\left(H_{3} L 1\right)$ : To a solution of salicylaldehyde (1.46 g, 12mmol) in diethyl ether $(12 \mathrm{~mL})$ was added tpt $(0.75 \mathrm{~g}, 4 \mathrm{mmol})$ in absolute ethanol $(12 \mathrm{~mL})$. After the addition of additional diethyl ether $(20 \mathrm{~mL})$ and cooling in an ice bath for $30 \mathrm{~min}$, the yellow precipitate formed was filtered off, washed with diethylether and dried in vacuo. Yield, 1.7g (85\%); mp 100-102 
${ }^{\circ} \mathrm{C}$; Found: $\mathrm{C}, 64.0 \%$; H, 7.6\%; N, 10.1\%. $\mathrm{C}_{30} \mathrm{H}_{36} \mathrm{~N}_{4} \mathrm{O}_{3} \cdot 3 \mathrm{H}_{2} \mathrm{O}$ requires: $\mathrm{C}, 65.0 \%$; H, 7.6\%; N, 10.1\%; ${ }^{1} \mathrm{H}-\mathrm{NMR}\left(\mathrm{CDCl}_{3}\right.$, ppm, $300 \mathrm{MHz}, \mathrm{Ar}=$ Aromatic ring): $\delta 2.17(\mathrm{~m}, 6 \mathrm{H}, 2-\mathrm{H}), 3.06(\mathrm{t}, 6 \mathrm{H}, 1-\mathrm{H}), 3.66(\mathrm{t}$, 6H, 3-H), 6.85 (m, 6H, Ar H), 7.24 (m, 6H, Ar H), 8.33 (s, 3H, 4-H), 12.80 (bs, 3H, OH); ${ }^{13} \mathrm{C}-\mathrm{NMR}$ $\left(\mathrm{CDCl}_{3}, \mathrm{ppm}, 300 \mathrm{MHz}\right): \delta 25.92(\mathrm{C}-2), 51.82$ (C-1), 56.33 (C-3), $119.64(\mathrm{C}-5), 117.67,119.30$, 132.94, 133.67 (C-7 to C-10), 162.36 (C-6), 167.96 (C-4); IR (Nujol mull) cm $\mathrm{cm}^{-1}$ : 3000-2300 (b, v- $v_{\mathrm{O}-\mathrm{H}}$ ), 1633.6, $1614.2(\mathrm{sh}), 1580,1496.6\left(\mathrm{~s}, v_{\mathrm{C}=\mathrm{N}}\right.$ and $v_{\mathrm{C}=\mathrm{C}}$ ); FAB MS (positive FAB in nitrobenzyl alcohol): $\mathrm{m} / \mathrm{z} 501\left(\mathrm{MH}^{+},\left[\mathrm{C}_{30} \mathrm{H}_{37} \mathrm{~N}_{4} \mathrm{O}_{3}\right]^{+}, 80 \%\right)$.

Tris(3-((4'-hydroxysalicylidene)imino)propyl)amine $\left(H_{3} L 2\right)$ : This compound was prepared analogously using 4-hydroxysalicylaldeyhde. Yield, $1.75 \mathrm{~g}(80 \%) ; \mathrm{mp}>170{ }^{\circ} \mathrm{C}$ (decom.); ${ }^{1} \mathrm{H}-\mathrm{NMR}$ (DMSO, ppm, 300MHz, Ar = Aromatic ring) $\delta: 1.05\left(\mathrm{t}, \mathrm{CH}_{3}-\mathrm{CH}_{2} \mathrm{OH}\right), 1.69(\mathrm{~m}, 6 \mathrm{H}, 2-\mathrm{H}), 2.43(\mathrm{t}, 6 \mathrm{H}$, 1-H), 3.4 (q, $\left.\mathrm{CH}_{3}-\mathrm{CH}_{2} \mathrm{OH}\right), 3.5$ (t, 6H, 3-H), 6.13 (m, 3H, Ar H), 6.21 (m, 3H, Ar H), 7.13 (m, 3H, Ar $\mathrm{H}), 8.30$ (s, 3H, 4-H), 12.80 (bs, 6H, OH); ${ }^{13} \mathrm{C}-\mathrm{NMR}$ (DMSO, ppm, $300 \mathrm{MHz}$ ) $\delta: 28.41$ (C-2), 51.08 (C-1), 54.97 (C-3), 111.43 (C-5), 103.02, 106.98, 133.62 (C-7, C-9, C-10), 162.11, 165.76 (C-6, C-8), 164.95 (C-4); IR (Nujol mull) $\mathrm{cm}^{-1}$ : 3500-2500 (broad weak band, $v_{\mathrm{O}-\mathrm{H}}$ ), 1636.8, 1607 sh (vs, $v_{\mathrm{C}=\mathrm{N}}$ ); FAB MS (positive FAB in nitrobenzyl alcohol): $\mathrm{m} / \mathrm{z} 549\left(\mathrm{MH}^{+},\left[\mathrm{C}_{30} \mathrm{H}_{37} \mathrm{~N}_{4} \mathrm{O}_{6}\right]^{+}, 20 \%\right)$.

\section{Complex Synthesis}

Both complexes were readily prepared by addition of $\mathrm{H}_{3} \mathrm{~L} 1(0.5 \mathrm{mmol}$ in $50 \mathrm{~mL}$ methanol) to a solution of the appropriate metal nitrate $(0.5 \mathrm{mmol}$ in the same solvent). After the addition of $\mathrm{NaOH}$ ( $3 \mathrm{mmol}$ in $10 \mathrm{~mL}$ methanol-water), the reaction mixture was heated for $30 \mathrm{~min}$. Evaporation of the solvent yielded the product as a green powder.

$\mathrm{Ni}(\mathrm{HL1}) \cdot 2 \mathrm{H}_{2} \mathrm{O}$ (1). Yield (0.18gr, 65\%); Found: C, 60.5\%; H, 5.6\%; N, 9.1\%. $\mathrm{C}_{30} \mathrm{H}_{38} \mathrm{~N}_{4} \mathrm{O}_{5} \mathrm{Ni}$ requires: $\mathrm{C}, 60.7 \%$; $\mathrm{H}, 6.4 \%$; N, 9.4\%; FAB MS (positive $\mathrm{FAB}$ in nitrobenzyl alcohol): $\mathrm{m} / \mathrm{z} 557\left(\mathrm{MH}^{+}\right.$, $\left.\left[\mathrm{C}_{30} \mathrm{H}_{35} \mathrm{~N}_{4} \mathrm{O}_{3} \mathrm{Ni}\right]^{+}, 62 \%\right)$. IR (Nujol mull) $\mathrm{cm}^{-1}: 3345\left(\mathrm{w}, v_{\mathrm{O}-\mathrm{H}}\right), 1629.5 \mathrm{~s}, 1610,1590,1533\left(v_{\mathrm{C}=\mathrm{N}}\right.$ and $v_{\mathrm{C}=\mathrm{C}}$.

$\mathrm{Cu}(H L 1)$ (2). Yield (0.17gr, 60\%); FAB MS (positive FAB in nitrobenzyl alcohol): $\mathrm{m} / \mathrm{z} 562\left(\mathrm{MH}^{+}\right.$, $\left.\left[\mathrm{C}_{30} \mathrm{H}_{35} \mathrm{~N}_{4} \mathrm{O}_{3} \mathrm{Cu}\right]^{+}, 55 \%\right)$. IR (Nujol mull) $\mathrm{cm}^{-1}: 3300$ (w, $\left.v_{\mathrm{O}-\mathrm{H}}\right), 1619,1599,1536.5\left(v_{\mathrm{C}=\mathrm{N}}\right.$ and $\left.v_{\mathrm{C}=\mathrm{C}}\right)$.

\section{References:}

1. Costes, J.-P.; Dupuis, A.; Commenges, G.; Lagrave, S.; Laurent, J.-P. Mononuclear lanthanide complexes of tripodal ligands: synthesis and spectroscopic studies. Inorg. Chim. Acta 1999, 285, 49-54.

2. Costes, J.-P.; Dahan, F.; Dupuis, A.; Lagrave, S.; Laurent, J.-P. Homo- (4f, 4f) and hetrodimethallic $\left(4 \mathrm{f}, 4 \mathrm{f}^{\prime}\right)$ Complexes. The first structurally characterized example of a 
hetrodimethalic (Yb, La) complex(1'). Magnetic properties of 1' and of a homodinuclear (Gd, Gd) analogue. Inorg. Chem. 1998, 37, 153-155.

3. Bhattacharyya, P.; Parr, J.; Ross, A. T.; Slawin. A. M. Z. First synthesis of a unique dilead Schiff base complex. J. Chem. Soc., Dalton Trans. 1998, 3149-3150.

4. Kanesato, M.; Yokoyama, T.; Itabashi, O.; Suzuki, T. M.; Shiro, M. Synthesis and Structural Characterization of praseodymium(III) and Neodymium(III) complexes of tripodal tris[2(salicylideneamino)ethyl]amine. Bull. Chem. Soc. Jpn. 1996, 69, 1297-1302.

5. Aguiari, A.; Bullita, E.; Casellato, U.; Guerriero, P.; Tamburini, S.; Vigato, P. A. Preparation, properties and coordination behaviour of planar or tridimentional compartmental Schiff bases. Inorg. Chim. Acta 1994, 219, 135-146.

6. Shuang, L;.Gelmini, L.; Rettig, S. J.; Thompson, R. C.; Orvig. C. Synthesis and characterization of lanthanide $[\mathrm{Ln}(\mathrm{L})]_{2}$ complexes of $\mathrm{N}_{4} \mathrm{O}_{3}$ amine phenol logands with phenolate oxygen bridges: evidence for very weak magnetic exchange between lanthanide Ions. J. Am. Chem. Soc. 1992, 114, 6081-6087.

7. Keypour, H.; Salehzadeh, S.; Pritchard, R. G.; Parish, R. V. Nickel(II) complexes of fully and partially condensed Schiff-base ligands derived from tris(3-aminopropyl)amine and acetylpyridine. Transition. Met. Chem. 1998, 23, 605-607.

8. Kirchner, R. M.; Mealli, C.; Baily, M.; House, N.; Torre, L. P.; Wilson, L. J.; Andrews, L. C.; Rose, N. J.; Lingafelter, E. C. The variable coordination chemistry of a potentially heptadentatecligand with a series of $3 \mathrm{~d}$ transition metal ions. The chemistry and structures of $\left[\mathrm{py}_{3} \text { tren) }\right]^{2+}$, where $\mathrm{M}(\mathrm{II})=\mathrm{Mn}, \mathrm{Fe}, \mathrm{Co}, \mathrm{Ni}, \mathrm{Cu}$ and $\mathrm{Zn}$ and (py 3 tren) = $\mathrm{N}\left\{\mathrm{CH}_{2} \mathrm{CH}_{2} \mathrm{~N}=\mathrm{C}(\mathrm{H})\left(\mathrm{C}_{6} \mathrm{H}_{4} \mathrm{~N}\right)\right\}_{3}$. Coord. Chem. Rev. 1987, 77, 89-163.

9. Jäntti, A.; Wagner, M.; Sountamo, R.; Kolehmainen, E.; Rissanen, K. Schiff-base podates - X-ray, $\mathrm{NMR}$ and $\mathrm{Ab}$ initio molecular-orbital studies of the cadmium(II) complexes of linear and threearmed podads in solution and solid state. Eur. J. Inorg. Chem. 1998, 1555-1562.

10. Keypour, H.; Salehzadeh, S.; Pritchard, R. G.; and Parish, R. V. Cadmium(II) complexes of fully condensed Schiff-base ligands derived from two different symmetrical and asymmetrical tripodal tetraamines and 2-acetylpyridine; the novel observations for heptadentate mono-capped trigonal antiprismatic Schiff-base complexes. Polyhedron 2000, 19, 1633-1637.

11. Keypour, H.; Stotter, D. A. Macrocycle synthesis. CR-type complexes displaying pendant ligation and $\mathrm{N}_{3} \mathrm{~S}$ coordination. Inorg. Chim. Acta 1979, 33, L149-151.

Sample Availability: Available from the authors.

(C) 2002 by MDPI (http://www.mdpi.org). Reproduction is permitted for non commercial purposes. 